\title{
変声障害に対する外科的治療の適応
}

\author{
庄司 和彦・児嶋 久剛・平野 滋

\section{Indications for Surgical Intervention in Treatment of Mutational Voice Disorder}

\author{
Kazuhiko Shoji, Hisayoshi Kojima and Shigeru Hirano \\ (Kyoto University)
}

In general, the primary therapy for mutational voice disorder is voice therapy since the disorder is believed to be mainly functional. However, we sometimes see organic changes such as slight vocal cord atrophy in some patients with mutational voice disorder who have mainly voice breaks as well as high pitch and hoarseness. We assume that asynchronous growth of the laryngeal cartilage and vocal cords might cause imbalance of tension of the vocal cords that results in atrophic appearance of vocal cord and prolonged mutational voice. When organic changes such as atrophy or tension imbalance of the vocal cords exist, voice therapy may not be effective and surgical treatment may yield better results.

We performed thyroplasty type III with lateral compression in three patients with mutational voice disorder with organic change. If the imbalance of the vocal cord tension causes mutational voice disorder associated with vocal cord atrophy, thyroplasty type III conbined with lateral compression may correct both the imbalance of the vocal cord tension and the glottal gap caused by vocal cord atrophy.

The effect of the operation was rapid and dramatic. In all three patients the voice pitch became much lower immediately after the procedure, and breathiness and voice breaks were reduced or disappeared. None of the patients required voice therapy after the operation. In conclusion, thyroplasty type III is quite effective for mutational voice disorder with unilateral vocal cord atrophy.

Key words: mutational voice disorder, thyroplasty type III, vocal cord atrophy

はじめに

声変わり(変声) は第 2 次性徵の 1 つと見なさ れる生理的現象で, $9 \sim 10$ 歳頃よりその徴候が 始まり17歳までには完了するとされている11. 日本人男子の変声期は $14 \sim 15$ 歳が最も多く, 女 子はこれよりやや早い2). 变声期の音声は粗造 性で, しばしば声の橎転を伴らが, 通常この様 な状態は 3 カ月〜 1 年で消失し成人の声に移行
する.すなわち男子では約 1 オクターヴ，女子 で約 3 度のピッチの低下をきたして安定化する. 一般に変声障害とは, 1 年以上変声期の音声が 持続するものを指し，その病態は機能的障害で, 背景には精神的因子が関与しているとされてい る11344). 従って治療は音声治療, 心理カウンセ リングが主役で，これらの治療により大部分の 症例は比較的早期に治瘉する。しかし，長年に 
わたる音声治療が無効の例もあり，これらには 器質的障害を伴っている可能性も考光られる. 今回, 軽度の一側声帯の萎縮様所見を呈した変 声障害に対し甲状軟骨形成術正型により良好な 成績を得た症例を経験したので，これらの症例 の呈示とともに変声障害の病態と外科的治療の 適応について考察した。

\section{対 象}

1988年12月～1994年 4 月の間に，当科で一側 声帯の萎縮様所見を伴ら变声障害 3 例に甲状軟 骨形成術而型を施行した。いずれも男性で，年 齢は18〜32歳, 平均 23 歳で, 病悩期間は $5 \sim 19$ 年であった. いずれも音声治療を 1 〜 年の長 期にわたり受けたが，無効であった。術前の喉 頭所見と発声機能検査所見を表に示寸. 全例に, 基本周波数 $(\mathrm{Fo})$ の上昇, $\mathrm{AC} / \mathrm{DC}$ の低下, 最大 発声持続時間 (MPT) の短縮と, 発声中の声の 眽転を認め, 左声帯の軽度の萎縮様所見を認め た.

\section{手 術 法}

声帯萎縮様所見による発声時声門間隙を認め るため，一側の側方圧迫を加えた甲状軟骨形成 術正型を採用した（図 1)。仰臥位にて，0.5\% エピネフリン入りキシロカインで局所浸潤麻酔 を施した後, 甲状軟骨切痕と甲状軟骨下縁との 中点のレベルに，患側(萎縮側)寄りに $4 \mathrm{~cm}$ の 水平皮膚切開を扮いた．前頸筋を外側に剝離し， 甲状軟骨を露出させ，正中より $1 \mathrm{~cm}$ 外側の甲 状軟骨板に縦切開を加光る。通常変声障害例は 若年者であるので，軟骨切開は11番のメスで容 易に行えるが，喉頭軟部組織まで切り込まない
よう注意する必要がある。この操作により軟骨 は2 片に分けられ，側方の軟骨片をある程度自 由に動かせるようになる。図1に示寸ように後 方の軟骨片前端を前方の軟骨片の下に置く事で, 患側の声帯は弛緩し，かつ内方に圧迫される. このときの音声と喉頭の内視鏡所見を参考に最 適な軟骨片の重なり具合を決め，両軟骨片を 2 本の 3-0ナイロン糸でマットレス縫合し固定 する，術創にはペンローズドレーンを挿入し， 皮膚縫合を行い手術を終了する。
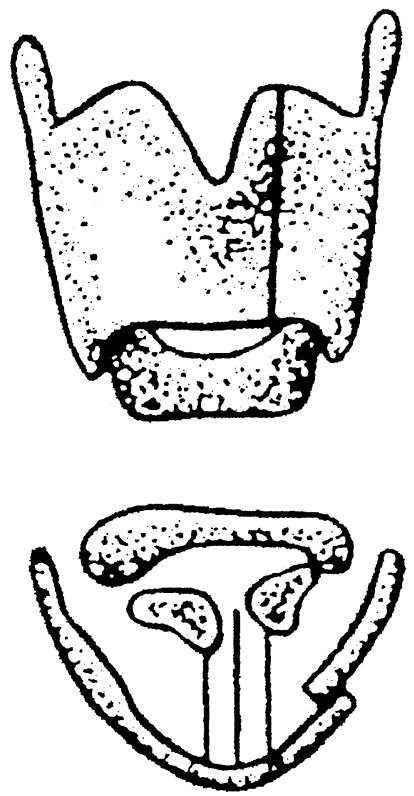

図 1 一側の側方圧迫を加兄た甲状軟骨形成 術 III型のシェーマ

（一色信彦：19779) より転載）

表 1 術前の発声機能検查所見と喉頭所見

\begin{tabular}{|c|c|c|c|c|c|c|c|}
\hline 症例 & $\begin{array}{r}\text { 年齢 } \\
\text { (荿) }\end{array}$ & $\begin{array}{l}\text { 音声治療 } \\
\text { の期間 (年) }\end{array}$ & $\begin{array}{l}\text { Fo } \\
(\mathrm{Hz})\end{array}$ & $\begin{array}{l}\mathrm{AC} / \mathrm{DC} \\
\text { (\%) }\end{array}$ & $\begin{array}{c}\mathrm{MPT} \\
(\mathrm{sec})\end{array}$ & 声の㼑転 & 喉頭所見 \\
\hline & 20 & 3 & 151 & 26 & 11 & + & 左声帯萎縮 \\
\hline & 32 & 3 & 231 & 17 & 11 & + & 左声帯萎 \\
\hline & 18 & 1 & 228 & 25 & 9 & + & 左声帯萎縮 \\
\hline
\end{tabular}


結果

術前後の Fo， $\mathrm{AC} / \mathrm{DC} ， \mathrm{MPT}$ の変化を図 2 に示す． 2 例に扮いて約 1 オクターヴのピッチ の低下を認め， 医ぼ正常な成人男性のピッチと なった。 1 例は術前のピッチの異常は軽度であ ったが術後やや低下した，AC/DC，MPT は著 明に改善して沶り, 声の翻転は全例に括いて術 後 $1 \sim 3$ カ月で完全に消失した。 術後の音声治 療は要さなかった。

代表的症例として術前の声の橎転が顕著であ った例を呈示する。

\section{症例}

患者 : 18歳, 男性.

主訴：声の眽転。

既往歴：特記すべき事なし。

家族歴：特記すべき事なし.

現病歴：12歳頃より声が出しにくくなり，13 歳頃より声の眽転が出現した。他院で音声治療 を受けるも軽快せず，平成 4 年 7 月 30 日（当時 16歳), 当科を受診した.

初診時所見：喉頭所見に異常を認めず，CT 上，両甲状軟骨板のなす角度は正常で，甲状軟 骨板の長さ, 声帯の長さ, 厚さに左右差を認め なかった（図 3 ). 声の基本周波数は $160 \mathrm{~Hz} て ゙$ やや上昇している程度であったが，声の䰤転が 顕著であった。

以上の所見より, 变声障害として Kayser-
Gutzmann 法などによる音声治療で経過観察し ていたが改善は見られなかった。そこで喉頭を よく観察すると, 左声帯が僅かに萎縮している ように見光 (図 4), この器質的障害が变声障害 の 1 つの原因と考光られた。

手術：平成 6 年 3 月 25 日 (18歳時), 左側の側 方圧迫を加えた甲状軟骨形成術而型を施行した。

術後経過：術後の CT で，左側甲状軟骨板前 後長の短縮による声帯の弛緩挆よび内方移動が 兄られていることがわかる(図 5 ). 術後 $1 \sim 2$ 週間は声のピッチの不安定さが残っていたが， 術後 1 カ月で, 声のピッチは安定し声の翻転は 完全に消失した。基本周波数は $160 \mathrm{~Hz}$ から $148 \mathrm{~Hz}$ に軽度低下した。術前術後の発声「や

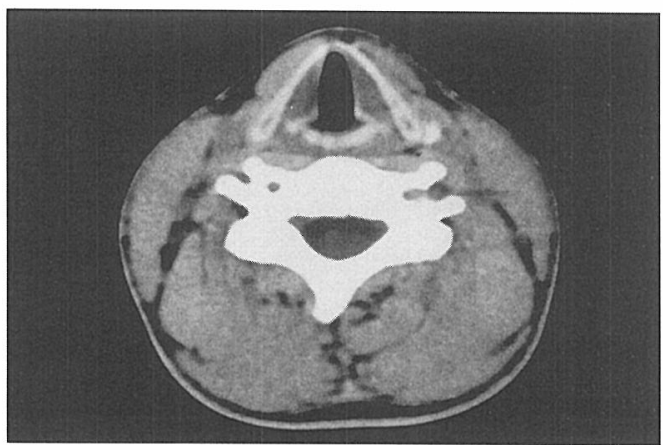

図 3 術前の喉頭の CT 所見 特に異常を認めない。
基本周波数

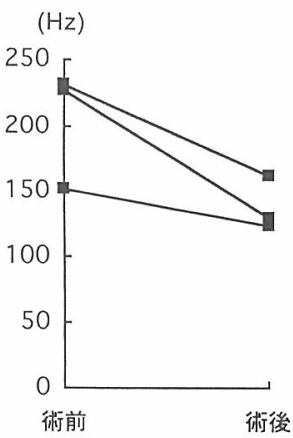

$\mathrm{AC} / \mathrm{DC}$

\author{
(\%)
}

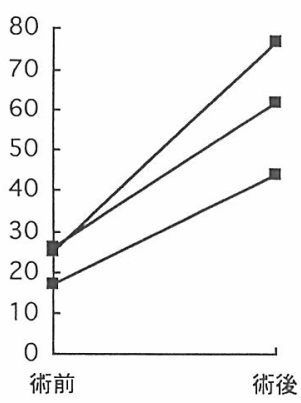

最大発声持続時間

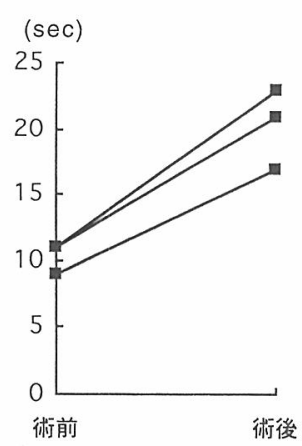

図 2 術前後の発声機能の変化 
ぶの中から鬼がぴょこんとでてきました」の音 声波形のらち, 声の眽転の著しかった部分を図 6 に示す。術前は，「やぶのなかから」の「や」 の最後から声の眽転が始まり「ぶのな」までピ ッチが著明に上昇しているが，術後はこの様な 所見は完全に消失し安定した音声波形になって いる。

\section{考察}

変声障害に関する文献は少なく114) 7)，その 病態は機能的障害とされ, 殆どの例が音声治療 で治瘉に至るとされている。 Weiss ${ }^{3)}$ は変声障 害を 5 つに分類している. 寸なわち,

(1) hypogonadism：性腺機能低下による喉 頭の成長障害に基づくもの.

(2) mutational falsetto voice : 変声期に適切 な発声法を修得せず，裏声が持続するもの.

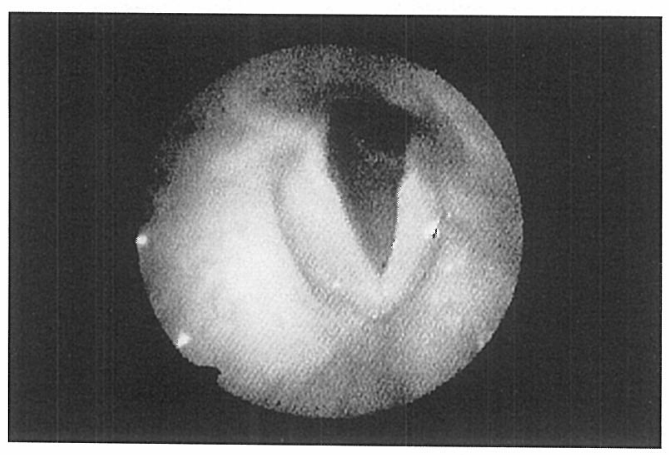

図 4 喉頭所見 左声帯の軽度の萎縮様所見を認める。
（3） incomplete mutation：変声期を過ぎて も十分にピッチが低下しないもの.

(4) mutational bass voice : 変声期に一時的 に生じる異常低音が持続するもの.

(5) perverse mutation：女子に見られる男 性的なピッチの低下を呈するもの.

これらの内, hypogonadism は類宦官症のよう な内分泌疾患をさし，いわゆる变声障害の範疇 からはずれると思われるが, 他の 4 つのタイプ はいずれも機能的障害とみなされている.

しかし, 臨床上よく遭遇する男子の変声障害 の中には, 今回呈示した症例のように, 器質的 障害が原因となっていると考光られるものが存 在する、変声障害は (1) 変声期を過ぎてもピッ チが成人の声位に下降しない型(持続性仮声) と (2) 声変わりが長引き, 声の眽転が持続する型

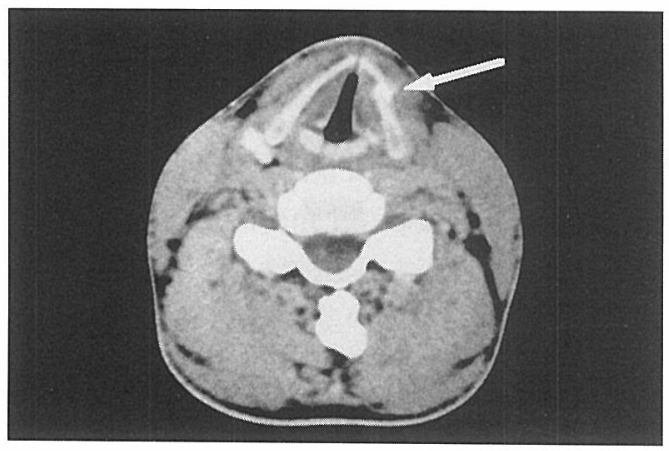

図 5 術後の喉頭の CT 所見 左声带 $(\rightarrow)$ の内方移動と驰緩が行われているのが わかる。

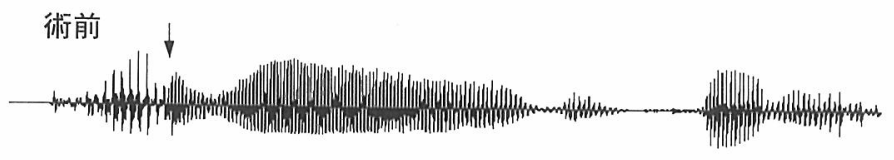

術後

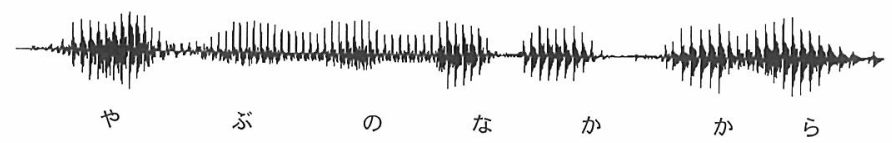

図 6 術前後のサウンドスペクトログラム

術前(上段)，「や」の終わりから䆏転が始まり，「ぶのな」まで著明 なピッチの上昇が持続しているが，術後(下段)は正常化している. 
(遷延性声変わり障害)の 2 つに分けられるとさ れている2). 前者は声の誤用による声帯の過緊 張が原因と思われるが，後者には器質的障害が 含まれている可能性があると思われる.この器 質的障害の成因として变声期の喉頭の発育過程 で，枠組み(軟骨部) と声帯を含む軟部組織との 成長速度に不均衡が生じ, 特に一側の軟部組織 の発育の後れがあると, 同側の声帯の緊張が高 まって, 両側声帯間の緊張不均衡による声の僠 転や二重音声などの発声障害をきたすことが考 えられる.また，この一側性声帯過緊張により 同側の声帯は萎縮様所見を呈するのではないか と思われる.

甲状軟骨形成術 III型8) は過緊張状態にある声 帯の弛緩を目的とした術式であり，一側に行う ことで片側の声带緊張の緩和が可能で, 同時に 声帯の軽度の側方圧迫を容易に加えることがで きる. 今回, 術前声の㼑転が著しく長期の音声 治療が無効であった症例に，一側の側方圧迫を 加えた甲状軟骨形成術 III型を施行し全症例に著 明な音声の改善を認めたことは，この様な音声 障害の器質的要因の存在を支持するものといえ る.

変声障害に対する音声治療は主に前頸部圧迫 法で，発声時に甲状軟骨切痕部を指で後下方に 圧迫する Kayser-Gutzmann 法, 甲状軟骨板を 左右から圧迫する藤田法, 正中線上で輪状甲状 膜部を押すWebeminsky 法などがあるが，こ れらは全ての変声障害の原因が機能的な声帯過 緊張によるといら考光に基づき, 正しい発声法 を患者に修得させることを目的としている，多 くの症例では以上のような音声治療が有効であ るにしても, 一側声帯の過緊張という器質的障 害が存在する場合は音声治療は無効で, 外科的 治療の適応と考兄られる. 音声治療が奏効しな い一側の声帯萎縮所見を認める症例には同側の 声帯過緊張の存在を疑い, 我々が行っているよ らな甲状軟骨形成術 III型に側方圧迫を加えた手 術を行らのが適当である.この手術手技は容易 で手術侵襲も少なく，また，術後に MPTゃ
$\mathrm{AC} / \mathrm{DC}$ の改善を見たことは，本術式が喉頭効 率の改善にも有効である事を示している. 変声 障害症例のらち器質的障害を疑わせる一側声帯 萎縮所見を呈するものには積極的に手術治療を 考慮すべきと思われる。

\section{まとめ}

一側声帯の萎縮様所見を呈し, 器質的障害が 原因と考学られた变声障害の 3 例に対し, 一側 の側方圧迫を加えた甲状軟骨形成術而型が有効 であった．この様な症例に対しては積極的に手 術治療を考慮すべさと思われた。

本論文の要旨は, 第 3 回国際音声外科シンポジウ 么 (於, 京都), 第56回耳鼻咽喉科臨床学会 (於, 鹿児 島)で発表した。

稿を終えるにあたり，ご校閲を賜りました本庄 嚴教授に深謝致します。

\section{文献}

1) Hammarberg $B:$ Pitch and quality characteristics of mutational voice disorders before and after therapy. Folia phoniatr $39: 204 \sim 216$, 1987.

2）切替一郎, 野村恭也：新耳鼻咽喉科学. 660 662頁, 南山堂, 東京, 1993.

3) Weiss DA : The pubertal change of the human voice. Folia Phoniatr $2: 126 \sim 159,1950$.

4) Kaplan SL : Mutational falsetto. J Am Acad Child Adolesc Psychiatry $21: 82 \sim 85,1982$.

5) Greene JS : The falsetto voice in the male; with a demonstration of four cured cases. Laryngoscope $31: 33 \sim 41,1921$.

6) Curry ET : The pitch characteristics of the adolescent male voice. Speech Monogr $7: 48$ $\sim 62,1940$.

7) Bridger MWM and Epstein R : Functional voice disorders; a review of 109 patients. J Laryngol Otol $97: 1145 \sim 1148,1983$.

8）一色信彦: 喉頭機能外科 -とくに経皮的アプ ローチー. 142 150頁, 京都大学医学部耳鼻咽 喉科同空会, 京都, 1977.

$$
\left.\begin{array}{l}
\text { 原稿受付 : 平成 } 6 \text { 年 } 8 \text { 月 } 10 \text { 日 } \\
\text { 原稿採択 : 平成 } 6 \text { 年 } 8 \text { 月 } 23 \text { 日 } \\
\text { 別刷請求先 : 庄司和彦 } \\
\text { 干 } 606-01 \text { 京都市左京区聖護院川原町 } 54 \\
\text { 京都大学医学部耳鼻咽喉科学教室 }
\end{array}\right)
$$

